\title{
Enhancing employee retention in supervisory support context: Role of person-organisations fit and career commitment
}

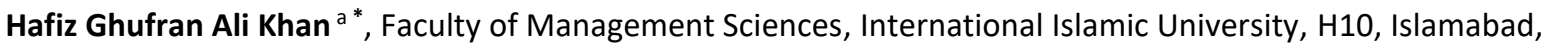 \\ 44000, Pakistan. https://orcid.org/0000-0002-8400-4302
}

\section{Suggested Citation:}

Khan, H.G.A. (2021). Enhancing employee retention in supervisory support context: Role of person-organisations fit and career commitment. Global Journal of Business, Economics and Management: Current Issues. 11(3), 178191. https://doi.org/10.18844/gjbem.v11i3.5434

Received from; July 2, 2021, revised from; September 17, 2021, accepted from; November 5, 2021 Selection and peer review under responsibility of Prof. Dr. Andreea lluzia IACOB, Bucharest Academy of Economic Studies, Romania.

${ }^{0} 2021$ Birlesik Dunya Yenilik Arastirma ve Yayincilik Merkezi. All rights reserved.

\begin{abstract}
Using social exchange theory (Blau, 1964), the current study examined the mediating effect of Career commitment in the relationship between supervisory support (SS) and employee retention (EE) and moderating role of Person Organisation Fit in the relationship between SS and Career Commitment. Specifically, the joint effect of mediating of career commitment and moderating role of Person Organisation Fit was examined. Data were collected from 264 respondents through questionnaire from Banking and Telecom sector (Rawalpindi and Islamabad) of Pakistan. The results show that SS has positive effect on employee retention and career commitment. The study further reveals that career commitment mediates the relationship between SS and Employee Retention and Person Organisation Fit moderates the relationship between SS and Career Commitment. The current study suggests that supervisors of banking and telecom sectors should support their subordinates to achieve their organisational goals effectively and efficiently. Person organisation fit is necessary for subordinates in organisations to complete their work and compete with their competitors.
\end{abstract}

Keywords: Supervisory support, career commitment, person-organisation fit, employee retention, supervisory;

* ADDRESS FOR CORRESPONDENCE: Hafiz Ghufran Ali Khan ${ }^{a}$, International Islamic University, Pakistan.

E-mail address: hafiz.ghufran@iiu.edu.pk 


\section{Introduction}

Support and assistance are needed for all social exchange (Blau, 1964). Supervisors mostly have control at workplace to retain employees in the interest of organisations (Eisenberger et al., 2002). It is imperative for an organisation to hire qualified and experienced personnel (Chan \& McAllister, 2014). Retaining employees is very important target for proper running of organisations as they spend huge investment in capacity building and skill development of their employees (Suifan et al., 2018; Sok et al., 2018). For enhancing and improving employee productivity, working environment plays a seminal role (lqbal et al., 2018).

Hiring of new employee is very costly and very difficult as compared to retaining employee who is already working in organisation (Alhmoud and Rjoub, 2019). Organisations take certain measures such as increasing salaries, providing amicable organisational environment, opportunities to develop career of employees and support of organisation to retain employee for longer period of time (Ali et al., 2018). Supports such as supervisory and co-workers are conducive for developing working environment to retain employee (Iqbal et al., 2018).

Some of the significant components of support are working environment and healthy work climate that encourage employee engagement with organisation is co-worker and supervisory support (SS), policies and procedures of organisation also play a key role (Shuck et al., 2018). Lancaster et al. (2015) managerial supportive environment encourage exchange ideas among employees to bring necessary changes like building good relationship among workers for improving productivity. Supportive work environment has a positive effect on employee productivity which shows their satisfaction and loyalty with the organisation (Hasyim \& Mangundjaya, 2019)

Satardien (2019) supervisory and organisational support help reducing the level of employee's quitting their jobs. An organisation having a supportive culture for employees is an inevitable measure to retain the potential employee in it (Lan, 2019). Perceived supervisor support reduces quitting intentions and enhances organisational loyalty (Hall, 2019). Support extends by supervisor positively affect job contentment and reduces turnover intention (Zhang et al., 2019).

Support from an organisation like SS leads cementing employee engagement (Rai et al., 2017).Those employees who are satisfied of the incentives provided by the employers hardly leave their jobs and want to continue their jobs (Ghosh et al., 2013). Employee retention in organisation can be ensured through reward, recognition, respect, better earning opportunities and working environment (Thoiba, 2018). Employee retention is defined that it is a technique to retain employees in an organisation for a good longer time than any other organisation where such supports are not common (Reina et al., 2018).

P O-fit is defined as "Like-mindedness between personnel and organisations becomes reality when employees provide what is needed for an organisation and vice versa (Kristof et al., 2018). PersonOrganisation fit of employee leads to job satisfaction (Rayton et al., 2019). Innovative behaviour of employees comes from person-organisation fit. Perceived social organisational supports help employee for innovative behaviour (Wojtczuk \& Turek, 2016). 
Career commitment can be described as attitudes of individual toward their career (Jehanzeb \& Mohanty, 2018). Career commitment leads to career success (Lee \& Eissenstat, 2018). Career commitment, a part of commitment that shows ones career, career commitment leads to positive career outcomes (Weng, 2018). Career commitment leads to success and satisfaction of individuals who have high level of self-efficacy (Singhal \& Rastogi, 2018). Career commitment positively effects career satisfaction in case of IT professions (Lo Presti et al., 2018).

The previous research shows that SS leads to employee retention through organisational engagement (Kundu \& Lata, 2017). Both supervisor and peer support enhance employee retention by taking certain measures which result improvement in their performance (Boakye et al., 2019).

The on-going study unearths the effect made by a supervisor on employee retention with the mediating role of career commitment and moderating role person-organisation fit in Pakistani context. Social exchange theory supports the current study (Blau, 1964). Social exchange generally takes place when supervisor provides support to the employee then the employee wants to stay with the organisation with their career commitment. Different researchers have studied social exchanges in different ways. The exchange occurs between supervisor and employee is called supervisory relationship (Eisenberger et al., 1986; Rhoades et al., 2001). If it is between employee and employees, then it is known as Peer group interaction (Ghosh and Sahney, 2011). Reciprocity of employees and organisation is called Perceived Organisational Support (Rhoades et al., 2001; Ghosh \& Sahney, 2011)

\section{Literature Review}

\subsection{Supervisor support and employee retention}

The support provided by a supervisor makes a person aware of the literature of an organisation which results good outcomes for it (Neves et al., 2018). "Human faces of an organisation are the Supervisors" (Dhanpat et al., 2018). SS guarantees good and amicable relationship between organisations and their employee. The better relationship between them leads to good image of the organisation. (Eisenberger et al., 2019) The workers who enjoy good relationship with supervisors hardly think to quit their job and organisation (Crane, 2019).

Employee's learning and training are strongly affected by the support of the manager (Ellstrom \& Ellstrom., 2014). Support provided by an organisation and a supervisor have strong impact on employee engagement (Rai et al., 2017). SS reduces job quitting intention and enhances job satisfaction (Chummar et al., 2019). Job retention and satisfaction are influenced by work experience (Taylor et al., 2017).

Social support reduces intention of quitting of an organisation and promotes adaptability with one's job (Karatepe \& Olugbage., 2017). The factors which effect employee retention are empowerment (Batra, 2017). Compensation, benefits and activities to develop an employee's skill and ability lead to employee retention (Renaud et al., 2015). Organisational, supervisor and co-worker support discourage job quitting intention (Duffy, 2019). SS and organisational support has a positive effect on job commitment and negative effect on turnover intention (Huyghebaert et al., 2019). 
Satisfaction with job is increased while anxiety is reduced by SS provided by a supervisor (Conrad. 2019). Compensation, opportunity for career and support by supervisor are important factors for employee retention (Shibiti, 2019). SS has direct relationship with the factors which contribute job retention (Potipiroon et al., 2019). SS encourages an employee to retain his job while it discourages turnover intention (Rhoades et al., 2001).

An employee in an organisation loves to work efficiently with a supervisor who is friendly, trustful and treats him respectfully (Chi et al., 2019). An employee in an organisation does not rage and work amicably if social support is offered by supervisors and other senior colleagues (Salamah et al., 2018). In most cases, employees leave their jobs because of not getting proper SS (Bolino, 2018)

Hence, in the light of the above study, the following hypothesis can be developed:

\section{H1. "Supervisory support is positively and significantly related to Employee Retention"}

\subsection{SS and career commitment}

A supervisor communicates the goals, value and objective to employees. His major and prime work is to evaluate the performance of employees (Yang, 2018). Employees feel them their true supporters and take them unbiased and active (Rahman et al., 2019). SS lessens the feeling of anxiety of an employee (Senreich et al., 2018). SS enhances awareness among employees about the literature of an organisation which is significant for the outcomes (Dai et al., 2018). "Human faces of an organisation are the Supervisors" (Gebre et al., 2019).

Employee commitment toward there career is affected by the supportive supervisor (Zheng and Wu, 2018). SS establishes strong relationship between an organisation and its employee (Dhanpat, 2018). The better relationship between employee and supervisor is good image of the organisation (Jadon \& Upadhyay, 2018). If an employer is true to his employees, the commitment of employees goes up (Naidoo, 2018). An employee likes his or her career due to support of their supervisor through their motivation (De Vito et al., 2018).

A supervisor plays the role of bridge between an organisation and its employees through psychological contact (Dhanpat et al., 2018). It is imperative to get SS so that the employees may have long-term and psychological link with their organisation (Ren et al., 2019). Job commitment is the outcomes of a SS and employee gets stronger when SS is offered with letter and spirit (Heffernan, 2018). SS reduces stress at workplace and improves performance of an organisation (Yang et al., 2018).

An employee wants to work with his current career for long term due to support of his supervisor at work place (Nagy et al., 2019). An employee wants to get success in his career which leads to organisational success due the support of ethical supervisor (Fehr et al., 2019). An ethical supervisor plays a key role to enhance employee career in organisational through career development counselling (Blokker et al., 2019). Career commitment of employee is effected by rewards system given by supervisors (Quadri, 2019).

On the basis of above study, we can come up with the following hypothesis: 
H2. "Supervisory support is positively and significantly related to Career Commitment"

\subsection{Career commitment and employee retention}

An employee's leaving an organisation does not only increase organisational cost but also reduces the standard of employee services (Olsen et al., 2019). The past researches show that employees leave their jobs due to low career development and opportunities (Haldorai et al., 2019). Turnover intention is affected negatively by career commitment (Masud et al., 2019) Career commitment has a strong and positive effect on employee retention because employees love their career and want to stay long term with the organisation (Haque et al., 2019).

The more committed an employee is with his job, the lower is the possibility of turnover (Haque et al., 2019). One of the most important factors of career commitment is career development which ultimately reduces job quitting intention (Van der Heijden et al., 2019). Lower career development results high turnover intention and high career development results higher employee retention (Haldorai et al., 2019; Yu et al., 2019).

Career commitment is referred as professional commitment, occupational commitment or career motivation (Lapointe et al., 2019). A professionally committed employee also wants to retain with organisation for long term (Glazer et al., 2019). An employee occupationally committed with their career wants to retain with an organisation for a longer period (Redditt et al., 2019). Employee retention is enhanced through career motivation (Koskey et al., 2019). Turnover intention is low when an employee is committed with his job (Asghar et al., 2018).

Most organisations do not provide job security to employees; therefore, career commitment is lower than that of employee friendly organisation. (Yu et al., 2019) Career commitment builds good and strong bounding between employees and organisation which leads to employee retention (Obiekwe et al., 2019). Employee retention is affected by employee commitment. Thus, they retain in the organisation happily (Yu et al., 2019). Job quitting intention is low when employees are full motivated toward their job (Lin et al., 2018).

Keeping in the view the above study following hypothesis can be developed:

H3. "Career commitment is positively and significantly related to Employee Retention"

\section{Mediation;}

\section{"Mediating effect of Career Commitment in the relationship between Supervisory support and Employee retention:"}

The two important antecedents of career commitment are perceived religious and social support (Huyghebaert et al., 2019). Committed to career leads to success and satisfaction of employee (Li et al., 2019). The more a person involved with his job, the lower is quitting intention (Lo Presti et al., 2018). An individual does lots of efforts for career development by developing certain qualities such as cognitive and intentional development (Afsar et al., 2019).

The individuals who are ready to be effective in their organisation are indeed committed to their professions thus they bear all kinds of difficulties to fit themselves to their careers (Redondo et al., 
2019). An employee commitment with an organisation does not only affected by individual identification but the specific career a person is seeking in that organisation (Duffy et al., 2011). Affective Commitment was demonstrated a valid mechanism to explain the relationship between employees' work experiences, on the one hand, and their turnover intentions as well as their wellbeing (Lapointe et al., 2013). Indeed, the previous research shows workplace commitment to have a positive effect on workers' attitudes, behaviour and work performance (Perreira et al., 2018). Affective commitment to the organisation is known to associate negatively with intended and actual turnover (Meyer et al., 2002).

Professional and organisational commitment mediates the relationship between recognition and professional employee's intention to stay (Valeau et al., 2019) Career commitment performs the role of mediator between training of employees and their job quitting intention (Kooij \& Boon, 2018). Career commitment mediates motivation, training and job quitting intention (Safavi \& Karatepe, 2018). The relationship between career commitment and core self-evaluation are mediated by career commitment (Singhal \& Rastogi, 2018). Career commitment mediates the relationship between training and job satisfaction (Duffy et al., 2011). Professional and organisational commitment mediates the relationship between training and professional employees intention to stay (Valeau et al., 2019).

Keeping view the above study, the following hypothesis can be propounded:

H4. "Career Commitment mediates the relationship between Supervisory support and Employee retention"

\section{Moderation;}

\section{"The relationship between supervisory support and career commitment is moderated by P-O-fit".}

P O-Fit is defined as the compatibility between an organisation and its employees becomes reality when the needs of one entity fulfil the needs of another entity (Kristof, 1996). Person-organisation fit positively influences salesperson's commitment and trust in manager (Schwepker, 2018).

Intention to stay with organisation is supported by ethical Person organisational fit and positive attitude (Boon, 2017). Person-Organisation fit of employee leads to job satisfaction. Supervisor support can minimise job stress of employee (Chen et al., 2016). Innovative behaviour of employee comes from person-organisation fit. Perceived social organisational climate supports employee for innovative behaviour (Wojtczuk \& Turek, 2016). Nurse person-organisation fit leads to innovative behaviour with doctor if she has high knowledge sharing behaviour (Afsar, 2016). Employee personorganisation fit leads to innovative behaviour with supervisor in the organisation (Afsar and Badir, 2016).

Person-organisation fit has positive effects on employee creativity (Sarac et al., 2014). Personorganisation fit has positive effect on job satisfaction and organisational commitment and negative effects on intention to leave (Sarac et al., 2017). Person-organisation fit is positively related to innovative behaviour (Afsar and Badir, 2017). Organisational ethical work environment has positively effects on person-organisation fit (Ruiz-Palomino et al., 2014). 
Different variables such as organisational citizenship behaviour, teaching and research productivity are positively affected by P O-fit (Akhtar et al., 2019). Job performance and job satisfaction also affected by P O-fit (Bogan and Dedeoglu, 2019). The general concept of Person organisation fit emphasis on commonality of organisational and personal qualities (Liu et al., 2010).

P O-fit moderates organisational commitment and turnover intention (Alniacik et al., 2013). The relationship between job satisfaction and public service motivation is moderated by person organisation fit (Liu et al., 2015). Job characteristic and reward are moderated by P O-fit (Jin et al., 2011). The relationship between ethical intent and ethical culture is moderated by P-O-Fit (Homberg \& Costello, 2019).

Keeping in view the aforementioned facts, the following hypothesis can be determined

H5. "Person-organisation fit moderates the relationship between Supervisory support and Career Commitment".

\subsection{Research model}

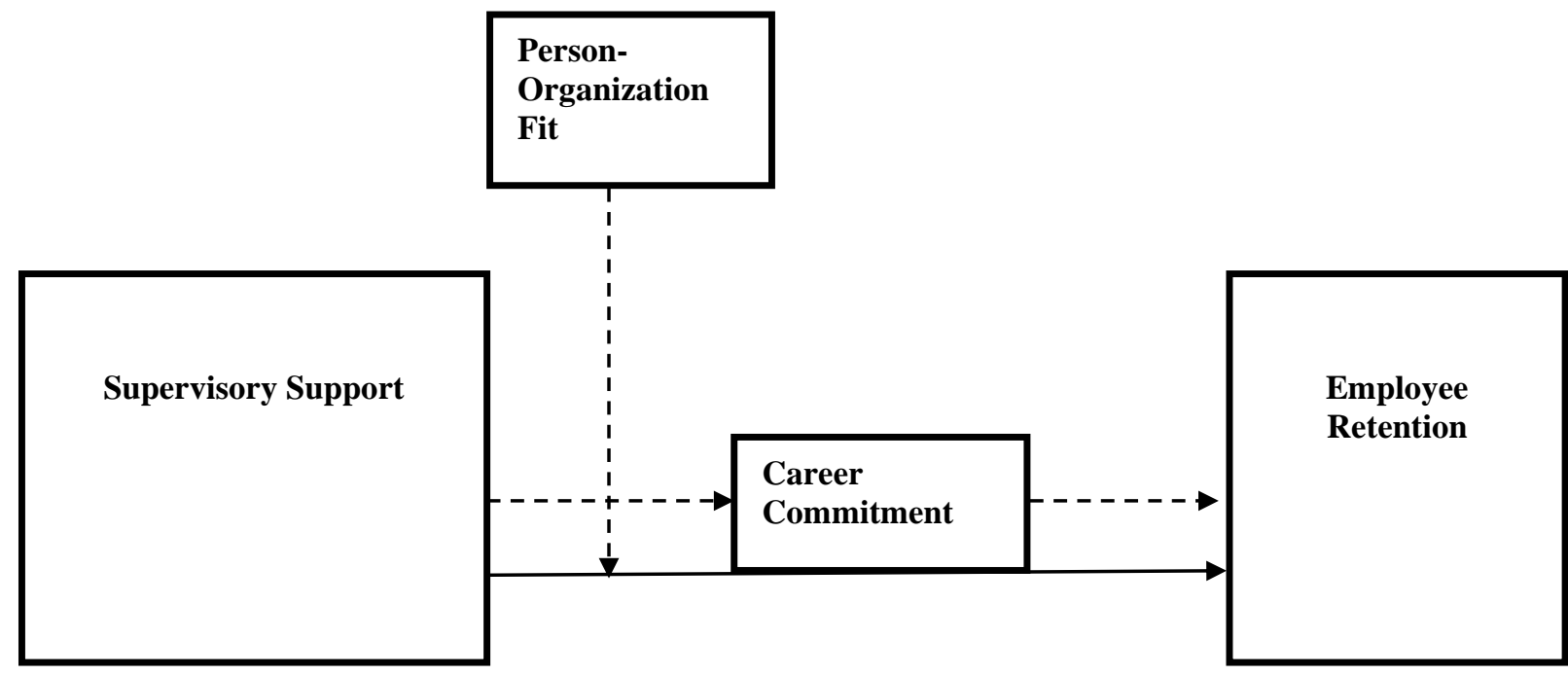

\section{RESEARCH METHODS}

The current study is empirical and quantitative based study. Data were collected by Convenience nonprobability sampling technique method through personal and professional contacts and collected from service organisation (Banking and telecom) in Pakistan. Field survey was conducted.

Time horizon of this research is cross-sectional as collected data in one-time frame from the respondent at different management level from banking and telecom sector.

One- way ANOVA was run in SPSS to gauge the amount of variation in dependent variable (Employee Retention) due to demographic variable such as age, gender and experience. Having performed oneway ANOVA no any significant difference was recorded in employee retention by gender, age and experience of employee. Table 1 shows the numerical value of One-way ANOVA.

Table 1. One-way ANOVA 


\begin{tabular}{lcc}
\hline $\begin{array}{l}\text { Sources of } \\
\text { variation } \\
\text { Gender }\end{array}$ & $\begin{array}{c}\text { ER } \\
\text { F statistics }\end{array}$ & p-value \\
Age & .212 & .646 \\
Experience & 1.877 & .134 \\
& .934 & .425 \\
\hline
\end{tabular}

\subsection{Correlation analysis}

Table 2 consists of means, standard deviation, reliabilities and correlation matrix:

Table 2. ???

\begin{tabular}{lllllll}
\hline & Mean & SD & $\mathbf{1}$ & $\mathbf{2}$ & $\mathbf{3}$ & 4 \\
SS & 3.67 & 0.61 & $(0.871)$ & & & \\
CC & 3.60 & 0.95 & $0.426^{* *}$ & $(0.732)$ & & \\
PO-F & 3.74 & 0.940 & $0.604^{* *}$ & $0.458^{* *}$ & $(0.792)$ & \\
ER & 3.42 & 0.98 & $0.503^{* *}$ & $0.416^{* *}$ & $0.512^{* *}$ & $(0.808)$
\end{tabular}

SS: Supervisory support, CC: Career commitment, PO-F: Person organisation fit, EE: Employee retention

Table 3 shows the positive correlation between SS and employee retention $(0.503, p=0.000)$ so after finding, hypothesis 1 is supported. The correlation between career commitment and SS have positive and significant relationship $(0.426, p=0.000)$ this positive finding supports to hypothesis 2 . Career commitment and employee retention have significant and positive correlation $(0.503, p=0.000)$; therefore, hypothesis 3 is supported.

\subsection{Mediation regression analysis}

Mediation condition of (Baron and Kenny, 1986) is used in current study to find out the mediating role of career commitment. To find out the main effect as well as the mediating effect in current study, we used regression analysis.

The finding shows that employee retention is effected positively and significantly by SS $(\beta=0.746, p<$ 0.001), so Hypothesis 1 is accepted.

Results shows that SS is positively and significantly effect on career commitment $(\beta=0.617, p<.001)$ so, Hypothesis 2 is accepted.

In addition the results shows the Employee retention is effected positively and significantly by career commitment $(\beta=0.933, p<0.001)$; therefore, hypothesis 3 is accepted.

Table 3. Regression analysis 
Predictor

\begin{tabular}{llllll}
\hline $\mathrm{B}$ & $\mathbf{R}^{2}$ & $\Delta \mathbf{R}^{2}$ & $\mathrm{~B}$ & $\mathbf{R}^{2}$ & $\mathbf{R}^{2}$
\end{tabular}

Direct effect

SS

$\mathrm{N}=2$ 264. SS = Supervisory Support, CC $=$ Career commitment. ${ }^{*}=\mathrm{p}<0.05 .{ }^{* *}=\mathrm{p}<0.01 .^{* * *}=\mathrm{p}<0.001$. ns $=$ Not significant.

Table 3 shows the positive and significant relationship between SS and employee retention is mediated by career commitment find out through mediating regression analysis $(\beta=0.208, p=0.000$; $\left.\Delta \mathbf{R}^{2}=0.848, p<0.001\right)$ and thus Hypothesis 4 is accepted.

\subsection{Moderation regression analysis}

Moderation regression analysis was run to test the moderating effect of PO-Fit in the relationship between SS and employee retention. Moderated regression analysis was used in the current study to find out the interactive effects of SS and person organisation fit on employee retention. First, the control variable was drop due to insignificant effect of control variable on employee retention, second SS along with person organisation fit was entered and finally interaction term of SS and P-O-Fit was entered.

After a finding, we can say that Person organisation fit moderate the relationship between SS and Employee Retention. $\left(\beta=0.204, p<0.001 ; \Delta \mathbf{R}^{2}=0.613, p<0.001\right.$ ) which means $1 \%$ change in interaction term of SS and Person organisation Fit causes to effect Employee retention by $61 \%$.

Hence, in the light of above finding, we can say that hypothesis 5 is accepted.

\subsection{Moderated regression analysis}

Table 4. ??? 
Khan, H.G.A. (2021). Enhancing employee retention in supervisory support context: Role of person-organisations fit and career commitment. Global Journal of Business, Economics and Management: Current Issues. 11(3), 178-191. https://doi.org/10.18844/gjbem.v11i3.5434

Predictor

B

\section{Step 1}

SS

$0.746 * * *$

POF

$0.834^{* * *}$

\section{Step 2}

SS $\times$ POF

\section{Employee retention}

$\mathbf{R}^{2}$

$\Delta \mathbf{R}^{\mathbf{2}}$ 
high person organisation fit and weakest in the case of low person organisation fit. In case of high person organisation fit interaction plot shows positive relation between SS and career commitment and in case of low person organisation fit interaction plot shows negative relation between SS and career commitment.

\section{Discussion}

All proposed hypothesis are supported and accepted by the current study. Employee retention is positively affected by SS. Employee retention is guaranteed by organisational support and friendly environment. SS builds up the sense of satisfaction in an employee with his job and convinced and motivated employees continue their services for the organisation.

SS reduces turnover intention and enhances employee retention. Employee retention is influenced by the following supervisory mechanism like rewards. Its may be financial as well as verbal. Promotion is another form of support which is based on appraisal of employee each year supportive supervisor follow $360^{\circ}$ performance appraisal.

The findings of current study is supported by the previous researches done by (Batra, 2017 ; Renaud et al., 2015 ; Karatepe \& Olugbage, 2017; Taylor et al., 2017; Rai et al., 2017; Ellstrom \& Ellstrom, 2014; Dhanpat et al., 2018).

Career commitment is affected significantly and positively by SS. SS plays a pivotal role in many organisations for career development or career success. SS helps an employee to develop his/her skills in his relevant field to cope with the challenges related to his/her profession.

Motivational tool is the most significant measures which a supervisor uses for achieving organisational goals. In this way, career development of an employee is made. Thus, he/she becomes well-rounded in his profession. The findings of current study are supported by the previous researches done by (Yang et al., 2018; Dhanpat et al., 2018; Naidoo, 2018; Jadon \& Upadhyay, 2018; Dhanpat, 2018; Dai et al., 2018; Senreich et al., 2018; Yang., 2018).

Employee retention is positively and significantly affected by career commitment. Career commitment of an employee is committed with his job in an organisation. Employee retains in the firm happily which is considered success of that organisation. In case of career commitment, there will be low turnover intention.

The findings of current study are supported by the previous researches done by (Masud et al., 2019; Haque et al., 2019; Van der Heijden et al., 2019; Haldorai et al., 2019; Lapointe et al., 2019; Obiekwe et al., 2019).

The relationship between SS and employee retention is moderated by $\mathrm{P} \mathrm{O}$-fit. The more higher P O-fit is in any organisation, the more will be career commitment or professional commitment in case of SS. The findings of current study are supported by the previous researches done by (Liu et al., 2015; Jin et al., 2011; Alniacik et al., 2013; Liu et al., 2010; Schwepker, 2018; Kristof, 1996). 


\section{References}

Afsar, B. (2016). The impact of person-organization fit on innovative work behavior: The mediating effect of knowledge sharing behavior. International Journal of Health Care Quality Assurance, 29(2), 104-122.

Afsar, B., \& Badir, Y. (2016). The mediating role of psychological empowerment on the relationship between person-organization fit and innovative work behavior. Journal of Chinese Human Resource Management, 7(1), 526.

Afsar, B., \& Badir, Y. (2017). Workplace spirituality, perceived organizational support and innovative work behavior: The mediating effects of person-organization fit. Journal Workplace Learning, 29(2), 95-109.

Afsar, B., Umrani, W. A., \& Khan, A. (2019). The impact of perceived calling on work outcomes in a nursing context: The role of career commitment and living one's calling. Journal of Applied Biobehavioral Research, 24(1), 12154.

Akhtar, M. W., Syed, F., Husnain, M., \& Naseer, S. (2019). Person-organization fit and innovative work behavior: The mediating role of perceived organizational support, affective commitment and trust. Pakistan Journal of Commerce and Social Sciences (PJCSS), 13(2), 311-333.

Alhmoud, A., \& Rjoub, H. (2019). Total rewards and employee retention in a middle eastern context. SAGE Open, 9(2), 2158244019840118.

Ali, F. H., Rizavi, S. S., Ahmed, I., \& Rasheed, M. (2018). Effects of perceived organizational support on organizational citizenship behavior-Sequential mediation by well-being and work engagement. Journal of the Punjab University Historical Society, 31(1), 1-9.

Alniacik, E., Alniacik, U., Erat, S., \& Akcin, K. (2013). Does person-organization fit moderate the effects of affective commitment and job satisfaction on turnover intentions? Procedia-Social and Behavioral Sciences, 99, 274-281.

Asghar, M., Gull, N., Bashir, M., \& Akbar, M. (2018). The impact of work-family conflict on turnover intentions: The moderating role of perceived family supportive supervisor behavior. Journal of Hotel and Business Management, 7(178), 2169-0286.

Baron, R. M., \& Kenny, D. A. (1986) The moderator-mediator variable distinction in social psychological research: Conceptual, strategic, and statistical considerations. Journal of Personality and Social Psychology, 51(6), 1173.

Boakye, K. G., Apenteng, B. A., Hanna, M. D., Kimsey, L., Mase, W. A., Opoku, S. T., \& Peden, A. (2019). The impact of interpersonal support, supervisory support, and employee engagement on employee turnover intentions: Differences between financially distressed and highly financially distressed hospitals. Health Care Management Review, 46(2), 135-144.

Bogan, E., \& Dedeoglu, B. B. (2019). The influence of corporate social responsibility in hospitality establishments on students' level of commitment and intention to recommend. Journal of Hospitality, Leisure, Sport and Tourism Education, 25, 100205.

Chen, P., Sparrow, P., \& Cooper, C. (2016) The relationship between person-organization fit and job satisfaction. Journal of Managerial Psychology, 31(5), 946-959.

Chi, N. W. (2019) Is support always good? Exploring whether supervisory support enhances or attenuates the beneficial effect of positive group affective tone on team and individual creativity. Emotions and Leadership Research on Emotion in Organizations, 15, 133-157.

Duffy, M. E. (2019). Concerted Management Support in New Graduate RNS: What's It All About?

Duffy, R. D., Dik, B. J., \& Steger, M. F. (2011). Calling and work-related outcomes: Career commitment as a mediator. Journal of Vocational Behavior, 78(2), 210-218. 
Eisenberger, R., Huntington, R., Hutchison, S., \& Sowa, D.(1986). Perceived organizational support. Journal of Applied Psychology, 71(3), 500-507.

Fehr, R., Welsh, D., Yam, K. C., Baer, M., Wei, W., \& Vaulont, M. (2019). The role of Morale coupling in the causes and consequences of unethical pro-organizational behavior. Organizational Behavior and Human Decision Processes, 153, 27-40.

Ghosh, K., \& Sahney, S. (2011). Impact of organizational socio technical system on managerial retention: A general linear modeling approach. Journal of Modeling in Management, 6(1), 33-59.

Glazer, S., Mahoney, A. C., \& Randall, Y. (2019). Employee development's role in organizational commitment: A preliminary investigation comparing generation $\mathrm{X}$ and millennial employees. Industrial and Commercial Training, 51(1), 1-12.

Haldorai, K., Kim, W. G., Pillai, S. G., Park, T. E., \& Balasubramanian, K. (2019). Factors affecting hotel employees' attrition and turnover: Application of pull-push-mooring framework. International Journal of Hospitality Management, 83, 46-55.

Hall, M. D. (2019). Relationship between Employee Development, Employee Burnout, and Employee Turnover Intentions.

Haque, A., Fernando, M., \& Caputi, P. (2019). The relationship between responsible leadership and organisational commitment and the mediating effect of employee turnover intentions: An empirical study with Australian employees. Journal of Business Ethics, 156(3), 759-774.

Homberg, F., \& Costello, J. (2019). Public Service Motivation and Civic Engagement: The Role of Pro-social Motivations in Shaping Society. Berlin, Germany: Springer.

Huyghebaert, T., Gillet, N., Audusseau, O., \& Fouquereau, E. (2019). Perceived career opportunities, commitment to the supervisor, social isolation: Their effects on nurses' wellbeing and turnover. Journal of Nursing Management, 27(1), 207-214.

Karatepe, O. M., \& Olugbade, O. A. (2017). The effects of work social support and career adaptability on career satisfaction and turnover intentions. Journal of Management andOrganization, 23(3), 337-355.

Potipiroon, W., \& Ford, M. T. (2019). Relational costs of status: Can the relationship between supervisor incivility, perceived support, and follower outcomes be exacerbated? Journal of Occupational and Organizational Psychology, 92(1), 1-38.

Rahman, A. U., Shah, F. A., \& Jan, S. (2019). The moderating role of supervisory support in the relationship of emotional intelligence and job performance of pharmaceutical sales representatives. Review of Economics and Development Studies, 5(1), 11-22.

Ren, S., Yang, F., \& Wood, R. (2019). How work-related capabilities influence job performance: A relational perspective. The International Journal of Human Resource Management, 30(7), 1157-1180.

Renaud, S., Morin, L., Saulquin, J. Y., \& Abraham, J. (2015). What are the best HRM practices for retaining experts? A longitudinal study in the Canadian information technology sector. International Journal of Manpower, 36(3), 416-432.

Taylor, L. L., Beck, M. I., Lahey, J. N., \& Froyd, J. E. (2017). Reducing inequality in higher education: The link between faculty empowerment and climate and retention. Innovative Higher Education, 42(5-6), 1-15.

Valeau, P., Paille, P., Dubrulle, C., \& Guenin, H. (2019). The mediating effects of professional and organizational commitment on the relationship between HRM practices and professional employees. The International Journal of Human Resource Management, 32(8), 1-37.

Yu, Q., Yen, D. A., Barnes, B. R., \& Huang, Y. A. (2019). Enhancing firm performance through internal market orientation and employee organizational commitment. The International Journal of Human Resource 
Khan, H.G.A. (2021). Enhancing employee retention in supervisory support context: Role of person-organisations fit and career commitment. Global Journal of Business, Economics and Management: Current Issues. 11(3), 178-191. https://doi.org/10.18844/gjbem.v11i3.5434

Management, 30(6), 964-987.

Zhang, X., Ma, L., Xu, B., \& Xu, F. (2019). How social media usage affects employees' job satisfaction and turnover intention: An empirical study in China. Information and Management, 56(6), 103136.

Zheng, J., \& Wu, G. (2018). Work-family conflict, perceived organizational support and professional commitment: A mediation mechanism for Chinese project professionals. International Journal of Environmental Research and Public Health, 15(2), 344. 